\title{
KEANEKARAGAMAN DAN KEPADATAN ECHINOIDEA DAN ASTEROIDEA DI RATAAN TERUMBU KARANG PERAIRAN TONGKAINA DAN BAHOWO KOTA MANADO
}

\author{
(Diversity and density of Echinoidea and Asteroidea in coral reef flat of \\ Tongkaina and Bahowo waters Manado city)
Ailen Imanuel Eman*, Erly Yosef Kaligis, Chatrien Annita Luzianna Sinjal , Billy Theodorus Wagey \\ Program Studi IImu Kelautan Fakultas Perikanan dan IImu Kelautan \\ Universitas Sam Ratulangi, Manado \\ *e-mail: Ailenimanueleman19@gmail.com
}

\begin{abstract}
The waters of Tongkaina, which are part of northern Manado's waters, are known to have mangrove, seagrass, and seaweed ecosystems. Therefore efforts are needed to manage the population and diversity of echinoderms in these waters. Echinoderms' ecology has an essential role in maintaining the marine ecosystem's balance, which plays a role in recycling nutrients. This study aimed to determine diversity, species density, species relative density, species frequency, species relative frequency, dominance, and the index of importance of Echinoidea and Asteroidea's species in the waters of the Tongkaina Village and their density. The method used in this research is the quadratic line transect method. First of all, the survey was conducted to the sampling site's location in the coral reef flats of Tongkaina Village's waters, including Tongkaina beach and Bahowo beach, before operating the sampling. Then the observation stations were determined, namely Tongkaina waters (near Batu Meja) and Bahowo waters. The quadratic line transect method is used in this research.

Species of class Echinoidea and Asteroidea in the quadrat were recorded among the total of individuals, and the species is documented. This study's results indicate that six species were found, including the survey, and five species were found based on the line transect method with 182 individuals. Including Asteroidea 85 Individuals and Echinoidea 99 Individuals. Value of Diversity at station 1 has a value of $H^{\prime}=1.170$ with a dominance of $C=$ 0.364 , while at Station 2 has a value of $\mathrm{H}^{\prime}=1.232$ and dominance value of $\mathrm{C}=0.316$. the highest density in Station 1 is Diadema savigny $1.967 \mathrm{ind} / \mathrm{m}^{2}$ relative $50.86 \%$, and Linckia laevigata with the highest frequency $\mathrm{Fi}=0.533$. The highest important value index is Diadema savigny, with a value of $81.09 \%$, while at station 2 , the Protoreaster nodosus has the highest value of important value index with a value of $87.51 \%$. These species also have the highest density of $0.933 \mathrm{ind} / \mathrm{m}^{2}$ and a relative number of $41.79 \%$.
\end{abstract}

Keywords: Tongkaina, Echinoderm, Line Transect Quadrat Method, Asteroidea, Echinoidea, Coral Reef Flat

Perairan Tongkaina yang merupakan bagian dari perairan Manado bagian utara dikenal memiliki ekosistem mangrove, lamun, dan rumput laut. Oleh karena itu diperlukan upaya untuk mengelola populasi dan keanekaragaman Echinodermata di perairan tersebut. Ekologi Echinodermata memiliki peran penting dalam menjaga keseimbangan ekosistem laut, yang berperan dalam daur ulang unsur hara. Penelitian ini bertujuan untuk mengetahui keanekaragaman, kepadatan, kepadatan relatif, frekuensi, frekuensi relatif, dominasi, indeks nilai penting spesies kelas Echinoidea dan Asteroidea di perairan Desa Tongkaina. Metode yang digunakan dalam penelitian ini adalah metode transek garis kuadrat. Pertama, survei dilakukan di lokasi pengambilan sampel di rataan terumbu karang di perairan Desa Tongkaina, termasuk pantai Tongkaina dan pantai Bahowo, sebelum dilakukan pengambilan sampel. 
Kemudian telah ditentukan dua stasiun pengamatan yaitu perairan Tongkaina (dekat Batu Meja) dan perairan Bahowo. Metode transek garis kuadrat digunakan dalam penelitian ini.

Spesies dari kelas Echinoidea dan Asteroidea dalam kuadrat dicatat di antaranya adalah jumlah individu, dan spesies yang didokumentasikan. Metode yang digunakan dalam penelitian ini adalah metode Line Transek Kuadrat. Survei lokasi diadakan sebelum pengambilan data pada rataan terumbu karang perairan Kelurahan Tongkaina meliputi pantai Tongkaina dan pantai Bahowo. kemudian 2 stasiun pengamatan ditentukan yaitu perairan Tongkaina (dekat Batu Meja) dan perairan Bahowo. Metode Line Transek Kuadrat digunakan dalam peneltian ini. Jenis kelas Echinoidea dan Asteroidea pada kuadrat didata jumlah serta jenis dengan cara didokumentasi. Hasil penelitian ini menunjukan 6 spesies yang ditemukan dalam survei dan 5 spesies yang ditemukan berdasarkan metode line transek dengan Jumlah 182 individu. dan Asteroidea 85 Individu dan Echinoidea 99 Individu. Nilai keanekaragaman pada stasiun 1 memiliki nilai $H^{\prime}=1,170$ dengan dominasi $C=0,364$ sedangkan pada Stasiun 2 memiliki nilai $H^{\prime}=1,232$ dengan dominasi dengan nilai $\mathrm{C}=0,316$ stasiun 1 kepadatan tertinggi Diadema savigny $1,967 \mathrm{ind} / \mathrm{m}^{2}$ relatif $50,86 \%$. Nilai frekuensi Linckia laevigata dengan nilai 0,533. Nilai INP tertinggi Diadema savigny dengan nilai $81,09 \%$ sedangkan pada stasiun 2 Kepadatan tertinggi Protoreaster nodosus $0,933 \mathrm{ind} / \mathrm{m}^{2}$ relatif $41,79 \%$.dan nilai frekuensi tertinggi Protoreaster nodosus dengan nilai 0,533 nilai relatif 45,71 dan INP tertinggi Protoreaster nodosus dengan nilai $87,51 \%$

Kata kunci : Tongkaina, Echinodermata, Metode Line Transek Kuadrat, Asteroidea, Echinoidea Rataan Terumbu Karang

\section{PENDAHULUAN}

Echinodermata merupakan hewan invertebrata yang habitatnya tersebar di ekosistem laut mulai dari pantai sampai dengan kedalaman $366 \mathrm{~m}$. Echinodermata lebih memilih air dengan kualitas tertentu yang umumnya dapat ditemukan melimpah pada perairan yang jernih dan tenang (Radjab et al., 2014). Oleh karena itu tingkat keanekaragaman yang tertinggi terdapat di terumbu karang dan perairan dangkal (Rompis et al., 2013). Di wilayah manado, lokasi dengan keanekaragaman hayati tinggi terdapat di perairan Tongkaina yang dikenal memiliki ekosistem mangrove, lamun dan rumput laut.

Biota laut yang memiliki keanekaragaman tinggi terdapat dari filum echinodermata. Echinodermata merupakan jenis hewan yang berperan penting dalam pemeliharaan keseimbangan ekosistem, terutama pada ekosistem laut (Nontji, 1993). Keanekaragaman Echinoidea menjadi penentu kelimpahan dan sebaran tumbuhan laut di perairan dangkal. (Samuel et al., 2017. Asteroidea merupakan hewan yang menghasilkan dan memperkaya beragam bahan organik dari sedimen. Oreaster reticalus menelan gundukan sedimen dengan menhilangkan alga yang terdapat pada partikel, sedimen tersebut yang bertanggung jawab dalam penyebaran dan kelimpahan organisme seperti ikan, kepiting, dan bulu babi yang memakan sedimen (Rahman et al., 2018)

Penelitian

Keanekaragaman tentang terutama Asteroidea dan Echinoidea di pantai Tongkaina telah dilakukan oleh Bengkal, et al. (2019), Binambuni, et al. (1996) dan oleh Rompis et al., (2013). Perairan Tongkaina termasuk perairan Manado bagian Utara yang dikenal memiliki ekosistem mangrove, lamun dan rumput laut. Namun perlu upaya pengelolaan terhadap populasi dan keragaman Echinodermata di perairan tersebut. Untuk pengelolaan terhadap biota laut ini dibutuhkan informasiinformasi dasar khusunya mengenai jenis dan kelimpahan serta mengetahui hubungan dengan karakteristik habitatnya. (Ashari, 
2014) Lewat Penelitian ini adalah hasil tentang Echinoidea dan Asteroidea melalui teknik sampling dalam upaya mengatasi keterbatasan data informasi mengenai keberadaan hewan ini.

\section{METODE PENELITIAN}

Metode yang digunakan dalam penelitian ini adalah Metode Transek Kuadrat dalam penelitian ini dilakukan pengambilan data Keanekaragaman jenis, Kepadatan dan Kepadatan Relatif, Frekuensi dan Frekuensi Relatif, Dominasi, dam Indeks Nilai Penting. Sebelum penelitian dilakukan telah diadakan survei lokasi terlebih dahulu. Pada penelitian ini telah ditentukan 2 stasiun yaitu di perairan Tongkaina (dekat Batu Meja) dan pantai bahowo, dengan masing-masing stasiun 2 ditetapkan Tiga line transek sepanjang 100 meter ditarik dari posisi surut terendah ke arah laut. Pada tiap line transek tersebut dilakukan penjarakan 100 meter dan diatur jarak 10 meter untuk tiap kuadrat pada tiap line transek. Kuadrat yang digunakan berukuran $1 \times 1$ meter yang terbuat dari pipa silinder berukuran 1 meter dan berdiameter setengah inci diletakan di rataan terumbu, ke arah laut tegak lurus dengan garis pantai. Jarak antara garis transek yang satu dengan yang lain kurang lebih 25 meter. llustrasi petak contoh kuadrat pada line transek 1,2 dan 3 dapat dilihat pada (Gambar 1).

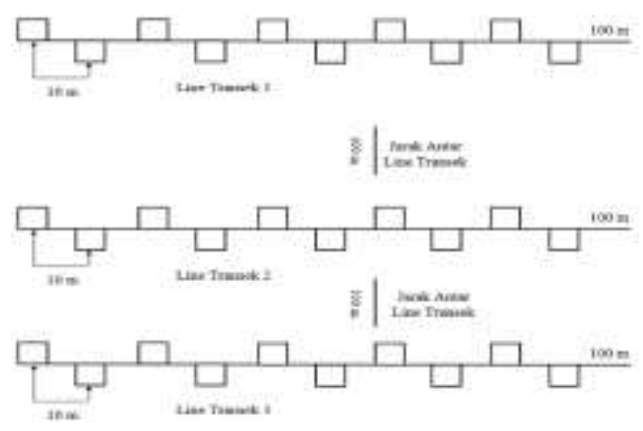

Gambar 1. Metode Transek Kuadrat
Selanjutnya semua jenis dari kelas Echinoidea dan Asteroidea yang berada dalam kuadrat didata jumlah dan jenisnya lalu di foto untuk tujuan memudahkan dalam identifikasi jenis.

\section{Waktu dan Lokasi Penelitian}

Lokasi penelitian berada di rataan perairan Kelurahan Tongkaina dan di rataan perairan Pantai Bahowo Kelurahan Tongkaina, Kecamatan Bunaken, Kota Manado. (Gambar 2).

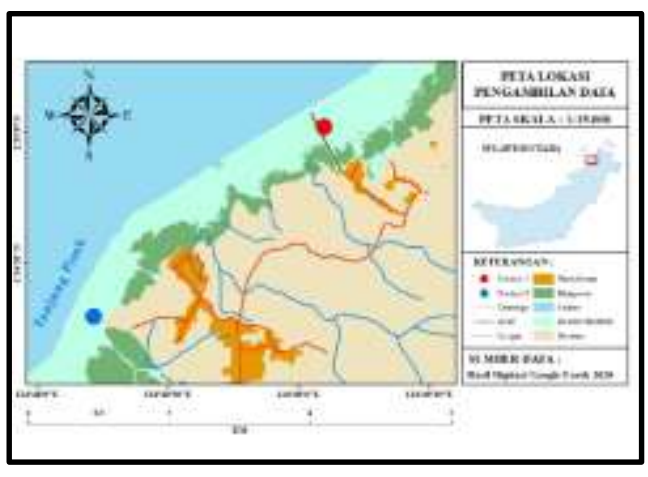

Gambar 2. Peta

Waktu pengumpulan data di lapangan pada bulan November Juni 2020. Pengambilan data dilakukan di rataan terumbu karang pada saat air surut. Hal ini dilakukan dalam mempermudah pelaksanaan pengambilan data dari Jenis Echinoidea dan Asteroidea. Sampel diidentifikasi dan difoto. Data berupa jumlah individu dan jenis.

\section{Keadaan Umum Lokasi Penelitian}

Titik koordinat stasiun lokasi penelitian ditunjukkan pada Tabel 1 . Stasiun 1 terletak di dekat pantai batu meja kelurahan Tongkaina, kecamatan Bunaken kota Manado; sedangkan lokasi stasiun 2 terletak di pantai Bahowo kelurahan Tongkaina, kecamatan Bunaken kota Manado

Tabel 1. Titik Koordinat Stasiun 


\begin{tabular}{|l|l|l|}
\hline No & Stasiun & \multicolumn{1}{|c|}{ Titik Kordinat } \\
\hline 1. & Stasiun 1 & $\begin{array}{l}1^{\circ} 35^{\prime} 33,897^{\prime \prime} \\
\text { LU } 124^{\circ} 49^{\prime}\end{array}$ \\
& & $43,287^{\prime \prime}$ BT \\
\hline 2. & Stasiun 2 & $\begin{array}{l}1^{\circ} 34^{\prime} 59,97^{\prime \prime} \text { LU } \\
124^{\circ} 49^{\prime} 5,61^{\prime \prime} \\
\text { BT }\end{array}$ \\
\hline
\end{tabular}

\section{Analisis Data}

Dalam penelitian ini data dapat diolah dengan menghitung nilai-nilai Keanekaragaman jenis, Kepadatan dan Kepadatan Relatif, Dominasi, Frekuensi dan Frekuensi Relatif, serta Indeks Nilai penting (Odum, 1971; Cox,1967; Odum,1994; Erlangga, 2018; Bengen, 2000; Brower, et al. 1989; Jumanto, 2013), sebagai berikut:

\section{a) Keanekaragaman Jenis $\left(\mathbf{H}^{\prime}\right)$}

Dalam mencari keanekaragaman digunakan rumus Indeks Shannonweaver (1949) dalam Odum (1971), sebagai berikut:

$$
H^{\prime}=-\sum \frac{n i}{N} \text { in } \frac{n i}{N}
$$

\section{Keterangan:}

H' : Indeks Keanekaragaman Shannon Weaver

Ini : Jumlah Tiap Jenis

$\mathrm{N}$ : Jumlah Total

b) Kepadatan (Di)

Indeks dalam karakter komunitas antar stasiun, yaitu nilai Kepadatan jenis. Dalam penganalisisan (Cox, 1967), sebagai berikut:

$$
D i=\frac{x}{Z}
$$

\section{Keterangan:}

$\mathrm{Di}=$ Kepadatan individu (ind $/ \mathrm{m}^{2}$ ) $\mathrm{x} \quad=$ Jumlah total individu yang teramati

$\mathrm{z}=$ Luas $\left(\mathrm{m}^{2}\right)$

c) Kepadatan Relatif (RDi)

Indeks dalam karakter komunitas antar stasiun, yaitu nilai Kepadatan
Relatif. Dalam penganalisisan (Cox, 1967), sebagai berikut:

$$
R D i=\frac{D x}{\sum D x} \times 100 \%
$$

\section{Keterangan:}

$\mathrm{RDi}=$ Kepadatan relatif

$\mathrm{Dx} \quad=$ Kepadatan pada tiap jenis

$\Sigma \mathrm{Dx}=$ Jumlah kepadatan semua jenis

d) Dominasi Spesies (C)

Indeks dalam karakter komunitas antar stasiun, yaitu nilai Dominasi spesies. Dalam penganalisisan (Odum, 1994) dalam (Erlangga, 2018), sebagai berikut:

$$
C=\sum(n i / N)^{2}
$$

\section{Keterangan:}

$\mathrm{C} \quad=$ Indeks Dominasi Spesies

ni = Jumlah Individu Spesies $\mathrm{i}$

$\mathrm{N} \quad=$ Jumlah Total Individu

Seluruh Spesies

\section{Kriteria Indeks Dominasi}

$0<\mathrm{C}<0,5 \quad$ : Tidak ada jenis yang mendominasi

$0,5<\mathrm{C}<1 \quad$ : Terdapat jenis yang mendominasi

e) Frekuensi Jenis (Fi)

Indeks dalam karakter komunitas antar stasiun, yaitu nilai Kepadatan Relatif. Dalam penganalisisan (Bengen, 2000), sebagai berikut:

$$
F i=P i / \sum P
$$

\section{Keterangan:}

$\mathrm{Fi} \quad=$ Frekuensi jenis

$\mathrm{Pi}=$ Jumlah petak ditemukannya suatu jenis

$\sum \mathrm{Pi}=$ Jumlah seluruh plot pengamatan

f) Frekuensi Relatif (RFi)

Indeks dalam karakter komunitas antar stasiun, yaitu nilai Kepadatan Relatif, Dalam penganalisisan (Bengen, 2000), sebagai berikut:

$$
R F i=F i / \sum F \times 100
$$

\section{Keterangan:}

$\mathrm{C}=$ Frekuensi jenis relatif

$\mathrm{Fi} \quad=$ Frekuensi jenis $\mathrm{i}$

$\Sigma \mathrm{F}=$ Frekuensi seluruh jenis 
g) Nilai Penting (INP)

Indeks dalam karakter komunitas antar stasiun, yaitu jumlah dari nilai Kepadatan Relatif dan Frekuensi Relatif, Dalam penganalisisan (Brower, et al. 1989) dalam Jumanto (2013), sebagai berikut:

\section{Keterangan:}

$$
I N P=R F i+R D i
$$

INP = Nilai Penting

$\mathrm{RDi}=$ Kepadatan relatif jenis

$\mathrm{RFi}=$ Frekuensi relatif jenis

HASIL DAN PEMBAHASAN

\section{a. Keanekaragaman Jenis}

Hasil analisis keanekaragaman jenis disediakan dalam Gambar 16 berikut.

Hasil analisa kuantitatif nilai indeks keanekaragaman jenis pada Stasiun 1 memiliki nilai $H^{\prime}=1,170$ sedangkan pada Stasiun 2 memiliki nilai $H^{\prime}=1,232$. Stasiun 2 memiliki nilai yang sedikit lebih tinggi dibandingkan dengan stasiun 1.

Jika tingkat keanekaragaman di suatu tempat yang semakin tinggi maka semakin baik pula kondisi tempat tersebut (Odum, 1993); (Insafitri I., 2010). Tinggi dan Rendahnya Keanekaragaman dalam suatu komunitas tergantung dari banyaknya jenis dan jumlah individu masing-masing jenis (Wilhm dan Dorris, 1986) dalam (Insafitri I., 2010).
Pengambilan data di stasiun 1 dan stasiun 2 memiliki tiga ekosistem di antaranya yaitu Mangrove, Lamun dan Terumbu karang. Namun lokasi di stasiun 2 yang memiliki aktivitas manusia yaitu menjadi tempat pariwisata.

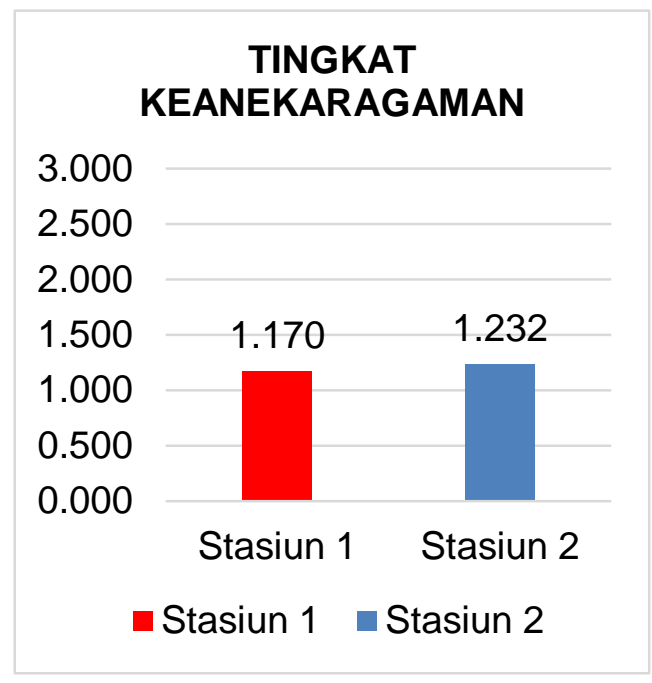

Gambar 1. Tingkat Keanekaragaman

\section{b. Kepadatan}

Hasil analisis kuantitatif kepadatan jenis menunjukkan beberapa spesies yang memiliki kepadatan tinggi dan rendah. Berdasarkan analisis kepadatan spesies, jenis Diadema savigny menunjukkan kepadatan tertinggi pada stasiun 1 yaitu $1,967 \mathrm{ind} / \mathrm{m}^{2}$ namun tidak diperoleh pada stasiun 2. Dengan nilai kepadatan relatif tertinggi di stasiun 1 yaitu $50,86 \%$ diduga karena spesies ini hidup secara berkelompok berjumlah besar dengan jarak yang sangat berdekatan dan memenuhi pada permukaan padang lamun. Sedangkan bintang laut jenis Protoreaster nodosus menunjukkan kepadatan terendah yaitu $0,1 \mathrm{ind} / \mathrm{m}^{2}$ dengan nilai relatif 2,59\%. Namun Jenis bintang laut Protoreaster nodosus menunjukkan nilai kepadatan yang tertinggi yaitu 0,933 $\mathrm{ind} / \mathrm{m}^{2}$ dengan nilai relatif $41,79 \%$ pada stasiun 2 sedangkan di stasiun 
1 terendah. Spesies ini seringkali dijumpai hidup dengan jumlah yang melimpah di substrat lamun, khususnya di daerah padang lamun.

Faktor yang mempengaruhi kepadatan populasi dan penyebaran pada spesies yaitu kedalaman, paparan ombak, tipe dan ukuran sedimen, komposisi bentik, bentuk geografis. (Bauer, 1980; Muthiga et al. 2007). Pertumbuhan populasi dari spesies dipengaruhi oleh adanya kompetisi di perairan dangkal. (McClanahan, 1992; Carpenter dan Edmunds 2006; Lessios, 2016). Protoreaster nodosus yang merupakan spesies yang didapati di padang lamun pantai Tongkaina dan Bahowo yang diduga cocok dengan lingkungan sehingga mampu mendominasi pada daerah bentik di area perairan dangkal intertidal.

Tabel 1. Kepadatan

\begin{tabular}{|l|l|l|}
\hline \multicolumn{3}{|c|}{ Kepadatan } \\
\hline Spesies & \multicolumn{1}{|c|}{$\mathbf{S 1}$} & \multicolumn{1}{c|}{ S2 } \\
\hline E. mathaei & 0,700 & 0,633 \\
\hline D. savigny & 1,967 & 0 \\
\hline P. nodosus & 0,1 & 0,933 \\
\hline L. laevigata & 1,033 & 0,133 \\
\hline A. typicus & 0,067 & 0,533 \\
\hline
\end{tabular}

Tabel 2. Kepadatan Relatif

\begin{tabular}{|l|l|l|}
\hline \multicolumn{3}{|c|}{ Kepadatan Relatif (\%) } \\
\hline Spesies & \multicolumn{1}{|c|}{ S1 } & \multicolumn{1}{c|}{ S2 } \\
\hline E. mathaei & 18,10 & 28,36 \\
\hline D. savigny & 50,86 & 0 \\
\hline P. nodosus & 2,59 & 41,79 \\
\hline L. laevigata & 26,72 & 5,97 \\
\hline A. typicus & 1,72 & 23,88 \\
\hline
\end{tabular}

\section{c. Dominasi}

Dominasi merupakan penyebaran jumlah individu pada tiap jenis, di antara tiap jenis tersebut terdapat spesies yang mendominasi di antara spesies lainnya. Gambar 18 terlihat bahwa stasiun 1 memiliki nilai dominasi lebih tinggi dibandingkan stasiun 2. Kriteria Odum, et al. (1995) maka stasiun 1 dengan nilai $\mathrm{C}=$ 0,364 masih termasuk pada kategori yang tidak ada jenis yang mendominasi atau nilai kurang dari 0,5 . Demikian juga stasiun 2 dengan nilai $C=0,316$ dalam kriteria Odum (1994) maka stasiun 2 jatuh pada kategori yang dengan tidak ada jenis yang mendominasi dengan ketentuan $\mathrm{C}=0<\mathrm{C}<0,5$.

Setiap spesies memiliki pengaruh secara langsung salah satu contohnya yaitu predasi dan secara tidak langsung seperti terjadinya perubahan struktur habitat. Kedua hal tersebut akan memberi dampak dan pengaruh terhadap penentuan spesies yang dominan (Convey, 2013 dalam Levin, 2013). Contoh perubahan habitat lainnya yaitu ada pada komunitas karang yaitu terjadinya peningkatan nutrien berlebihan akan menyebabkan pergeseran spesies yang dominan pada ekosistem tersebut (Levin 2013). Menurut Kambey, et al. (2015) daerah yang memiliki Ekosistem utama pada pesisir seperti Mangrove, Lamun dan Terumbu karang yang telah dialokasikan menjadi tempat pariwisata, akan memiliki dampak yang signifikan terhadap komunitas yang di dalamnya salah satunya komunitas Echinodermata yang di antara lain Bulu babi dan Bintang laut.

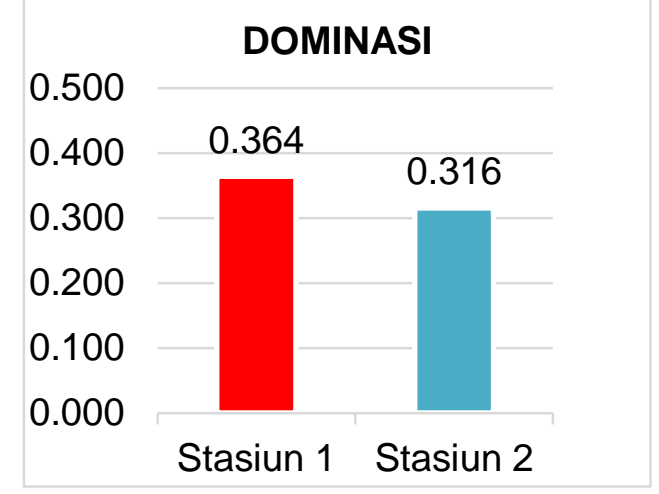

Gambar 2. Dominasi 


\section{d. Frekuensi}

Frekuensi adalah jumlah kehadiran suatu spesies di petak contoh hasil. Frekuensi jenis adalah jumlah peluang kehadiran spesies pada tiap plot pengamatan, jumlah kehadiran spesies per jumlah keseluruhan plot pengamatan (Bengen, 2000). Hasil analisis nilai frekuensi jenis dilampirkan pada Gambar 19. dan Hasil analisis nilai frekuensi jenis relatif pada Gambar 20.

Dalam penelitian ini menunjukkan beberapa spesies memiliki nilai frekuensi tertinggi dan terendah. Pada stasiun 1 spesies dengan nilai frekuensi tertinggi yaitu Linckia laevigata, hal ini diduga karena stasiun 1 yang memiliki ekosistem lamun disertai pecahan karang, dan substrat berpasir dan yang merupakan tempat spesies ini ditemukan. Sesuai dengan pernyataan Zamani (2015) Linckia laevigata dapat dijumpai pada kawasan terumbu karang dan hamparan padang lamun di daerah intertidal.

Nilai frekuensi tertinggi pada stasiun 2 yaitu Protoreaster nodosus. Spesies ini sering ditemukan pada daerah padang lamun. Schoppe (2000) menyatakan bintang laut Protoreaster nodosus dapat dijumpai pada daerah padang lamun di perairan dangkal dan dapat hidup dengan kedalaman 15 meter. Protoreaster nodosus umumnya memangsa mikroalga dan invertebrata kecil lainnya yang ada di daerah padang lamun.

Tabel 3. Frekuensi Jenis

\begin{tabular}{|l|l|l|l|}
\hline \multicolumn{4}{|c|}{ Frekuensi Jenis } \\
\hline No & Spesies & \multicolumn{1}{|c|}{ S1 } & \multicolumn{1}{|c|}{ S2 } \\
\hline 1. & E. mathaei & 0,700 & 0,633 \\
\hline 2. & D. savigny & 1,967 & 0 \\
\hline 3. & P. nodosus & 0,1 & 0,933 \\
\hline 4. & L. laevigata & 1,033 & 0,133 \\
\hline
\end{tabular}

\begin{tabular}{|l|l|l|l|}
\hline 5. & A. typicus & 0,067 & 0,533 \\
\hline
\end{tabular}

\section{e. Indeks Nilai Penting}

Indeks Nilai
digunakan untuk meng (INP)
penguasaan suatu jenis dalam
komunitas tertentu (Pamoengkas, et al. 2017). Gambar 31 menunjukkan nilai INP tertinggi pada stasiun 1 yaitu Diadema savigny dengan nilai $81,09 \%$ diikuti dengan Linckia laevigata dengan nilai $63,93 \%$ sedangkan nilai terendah adalah Archaster typicus dengan nilai $6,38 \%$. Spesies yang memiliki INP tertinggi pada stasiun 2 yaitu Protoreaster nodosus dengan nilai 87,51\% yang diikuti oleh Archaster typicus dengan nilai $52,45 \%$ dan nilai paling rendah yaitu pada spesies Linckia laevigata dengan nilai $17,40 \%$.

Pada stasiun 1 Diadema savigny ditemukan melimpah dan hidup berkelompok dengan jumlah yang besar. Spesies Bulu babi Linckia laevigata ditemukan hampir di seluruh plot pada ketiga line transek yang mana merupakan hamparan padang lamun, dan pecahan karang, sedangkan spesies dengan nilai terendah yaitu jenis bintang laut Archaster typicus yang mana mendiami pada substrat berpasir di stasiun 1. Namun Bintang laut spesies Protoreaster nodosus memiliki nilai INP tertinggi di stasiun 2 dengan nilai $87,51 \%$ yang diikuti oleh spesies Archaster typicus dengan nilai $52,45 \%$. Hal ini karena stasiun 2 berada dekat dermaga Bahowo yang mana juga merupakan tempat ekosistem padang lamun dengan substrat berpasir. Oleh sebab itu spesies ini diduga mengapa spesies ini memiliki INP yang tertinggi. Sedangkan spesies dengan nilai terendah jatuh pada bintang laut spesies Linckia laevigata, spesies ini sering ditemukan pada substrat 
lamun dan pecahan karang di stasiun 2. Hal ini sesuai dengan penelitian sebelumnya oleh Binambuni et al. (2019) telah menemukan bahwa Linckia laevigata di pantai Bahowo hanya menempati dua tipe substrat saja yaitu substrat lamun dan pecahan karang sedangkan Protoreaster nodosus menempati substrat pasir, lamun, pecahan karang.

Tabel 4. Indeks Nilai Penting

\begin{tabular}{|l|l|l|}
\hline \multicolumn{3}{|c|}{ Indeks Nilai Penting } \\
\hline Spesies & \multicolumn{1}{|c|}{$\mathbf{S 1}$} & \multicolumn{1}{c|}{ S2 } \\
\hline E. mathaei & 0,700 & 0,633 \\
\hline D. savigny & 1,967 & 0 \\
\hline P. nodosus & 0,1 & 0,933 \\
\hline L. laevigata & 1,033 & 0,133 \\
\hline A. typicus & 0,067 & 0,533 \\
\hline
\end{tabular}

\section{KESIMPULAN}

Berdasarkan penelitian yang dilakukan maka dapat di simpulkan,

1. Hasil identifikasi jenis Asteroidea dan Echinoidea diperoleh secara keseluruhan 6 spesies yaitu $E$. calamaris, $E$. mathaei, $D$. savigny, dan $P$. nodosus, $A$. typicus, $L$. laevigata.

2. Analisis beberapa parameter yang dilakukan yaitu
a. Nilai Keanekaragaman $H^{\prime}=1,170$ sedangkan pada Stasiun 2 memiliki nilai H' = 1,232 .

b. Nilai kepadatan Kepadatan dan Kepadatan Relatif, dengan Kepadatan tertinggi pada stasiun 1 , yaitu $D$. savigny $1,967 \mathrm{ind} / \mathrm{m}^{2}$ nilai relatif $50,86 \%$, dan nilai terendah $A$. typicus dengan nilai $0,067 \mathrm{ind} / \mathrm{m}^{2}$ nilai relatif $1,72 \%$. Sedangkan kepadatan tertinggi pada stasiun 2 yaitu $P$. nodosus $0,933 \mathrm{ind} / \mathrm{m}^{2}$ nilai relatif
$41,79 \%$. dan nilai terendah yaitu L. laevigata 0,133 ind $/ \mathrm{m}^{2}$ nilai relatif $5,97 \%$

c. Nilai dominasi Stasiun 1 memiliki nilai $\mathrm{C}=0,364$ yang jatuh pada kategori dengan tidak ada jenis yang mendominasi. Sama halnya pada Stasiun 2 dengan nilai $C=0,316$ sehingga jatuh pada kategori dengan tidak ada jenis yang mendominasi.

d. Nilai Frekuensi tertinggi pada stasiun 1 , yaitu $L$. laevigata 0,533 nilai relatif $37,21 \%$, Sedangkan nilai terendah yaitu pada dua spesies dengan nilai yang sama yaitu $A$. typicus 0,067 nilai relatif $4,65 \%$ sedangkan Frekuensi tertinggi pada stasiun 2 yaitu $P$. nodosus 0,533 nilai relatif $45,71 \%$ dan nilai terendah yaitu $L$. laevigata 0,133 nilai relatif $11,43 \%$

e. Indeks Nilai Penting yang tertinggi pada stasiun 1 yaitu Diadema savigny $81,09 \%$ dan nilai terendah yaitu $A$. typicus $6,38 \%$. Sedangkan pada stasiun 2 INP dengan nilai tertinggi yaitu $P$. nodosus $87,51 \%$ dan nilai terendah yaitu Linckia laevigata 17,40\%

\section{DAFTAR PUSTAKA}

Ashari, I. 2014. Struktur Dan Sebaran Komunitas Bintang Laut(Asteroidea) Di Perairan Pulau Sapudi, Kabupaten Sumenep, Madura. Jurnal Penelitian. Fakultas Perikanan Dan IImu Kelautan. IPB. Bogor

Bauer, J.C. 1980. Observations on geographical variations in 
population density of the echinoid Diadema antillarum within the western North Atlantic. Jurnal Bulletin of Marine Science Vol 30, Hal 509-515.

Bengen, D.G. 2000. Sinopsis Ekosistem dan Sumber Daya Alam Pesisir. Pusat Kajian Sumberdaya Pesisir dan Lautan - Institut Pertanian Bogor. Bogor.

Bengkal, K., Indri, M., Calvyn S., Billy W., Joshian S., Laurence, L. $2019 . \quad$ Identifikasi keanekaragaman lamun dan ekhinodermata dalam upaya konservasi. Jurnal Pesisir Dan Laut Tropis. Vol $7 \mathrm{Hal}$ 29.

Binambuni P., Lengoy M., Katili D. 2019. Keanekaragaman Jenis Bintang Laut di Pantai Bahowo Kecamatan Bunaken Kota Manado Sulawesi Utara. Program Studi Farmasi, Fakultas Matematika dan IImu Pengetahuan Alam Universitas Sam Ratulangi Manado. Vol. 8 No. 1

Brower, J.E., Zar J.H. dan Ende C.N.V. 1989. Field and Laboratory Method For General Ecology Fourth Edition. Mcgraw-Hill Publication. Boston, USA. Hal 273

Carpenter, R.C., dan Edmunds, P.J. 2006. Local And Regional Scale Recovery Of Diadema Promotes Recruitment Of Scleractinian Corals. Jurnal Ecology Letters Vol $9 \mathrm{Hal}$ 268-277.

Convey, P. 2013. Antarctic Ecosystems, Encyclopedia of Biodiversity, Vol $1 \mathrm{Hal}$ 179-188

Erlangga, S.Y, Sayyid A.E.R., Cut N.D. 2018. Struktur Komunitas Echinodermata di Perairan Pantai Gapang, Desa Iboih, Kecamatan Sukakarya, Program Studi IImu Kelautan, Fakultas Kelautan Perikanan, Universitas Syiah Kuala. Jurnal IImiah Mahasiswa Kelautan dan Perikanan Unsyiah

Insafitri, I. 2010. Keanekaragaman, Keseragaman, Dan Dominansi Bivalvia Di Area Buangan Lumpur Lapindo Muara Sungai Porong. Jurnal Kelautan: Indonesian Journal of Marine Science and Technology, Vol 3 No 1 Hal 54- 59.

Jumanto, A. P. dan Muzahar, 2013. Struktur Komunitas Echinodermata Di Padang Lamun Perairan Desa Pengudang Kecamatan Teluk Sebong Kabupaten Bintan Provinsi Kepulauan Riau Jurusan IImu Kelautan Fakultas IImu Kelautan Dan Perikanan Universitas Maritim Raja Ali Haji, Tanjungpinang. Jurnal Umrah.

Kambey, A.G., Andrea dan Rembet. Unstain dan Wantasen, Adnan, 2015 Komunitas Echinodermata Di Daerah Intertidal Perairan Pantai Mokupa Kecamatan Tombariri Kabupaten Minahasa. Fakultas Perikanan dan Ilmu Kelautan UNSRAT Manado. Jurnal IImiah PLATAX Vol. 3: Hal 12-13 
Lessios, H.A., 2016. The Great Diadema Antillarum Die-Off: 30 Years Later. Jurnal Annual Review of Marine Science 8, 267-283

Levin, S.A. 2013, Encyclopedia of biodiversity: Second edition. Elsevier Inc., Princeton University, Princeton, New Jersey, USA

McClanahan, T.R. 1992. Resource utilization, competition and predation: a model and example from coral reef grazers. Jurnal Ecological Modelling Vol 61 Hal 195215.

Muthiga, Nyawira dan Mcclanahan, Tim. 2007. Chapter 11 Ecology of Diadema. Jurnal Development in Aquaculture and Fisheries Science. Vol 37 hal 205- 225

Nontji, A. 1993. Pengolahan Sumberdaya Kelautan Indonesia Dengan Tekanan Utama Pada Perairan Pesisir. Prosiding Seminar Dies Natalis Universitas Hang Tuah . Surabaya.

Odum, E.P. 1971. Fundamental Of Ecology. Philadelphia London Toronto: W.B. Souders Company.

Odum, E.P. 1993. Dasar-dasar Ekologi. Terjemahan Tjahjono Samingan. Edisi Ketiga. Yogyakarta: Gadjah Mada University Press

Odum, H. 1994. Ecological and general systems : an introduction to systems ecology.

Odum, W.E. Eugen P.O., dan Howard, T.O. 1995. Nature's pulsing paradigm. Jurnal
Estuaries, Vol 18 Hal 547555.

Pamoengkas, P. dan Zamzam A.K., 2017. Komposisi Functional Species Group pada Sistem Silvikultur Tebang Pilih Tanam Jalur di Area luphhk$\mathrm{Ha}$ Pt. Sarpatim, Kalimantan Tengah, Departemen Silvikultur, $\quad$ Fakultas Kehutanan IPB, Jurnal Silvikultur Tropika Vol 08 No 3 Hal 160-169

Radjab, A., Rumahenga, S., Soamole, A., Polnaya, Dominggus, Barends, Wempy, 2014. Diversity And Abundance Of Echinoderms At Weda Bay Waters, North Maluku. Jurnal IImu dan Teknologi Kelautan Tropis Vol 6

Rahman, M.A. dan Molla M. H. R. dan Megwalu, Ferdinard dan Oe, Asare dan Mm, Shaikh, 2018. The Sea Stars (Echinodermata:

Asteroidea): Their Biology, Ecology, Evolution and Utilization. World Fisheries University Pilot Programme, Pukyong National University (PKNU), Nam-gu, Busan, Korea. Biotechnology and Genetic Engineering Discipline, Khulna University, Khulna, Bangladesh

Rompis, B.R., Marnix L., Katili, D., Adelfia P. 2013. Diversitas Echinodermata di Pantai Meras Kecamatan Bunaken Sulawesi Utara (Diversity of Echinoderms on the Meras Beach, Bunaken District, North Sulawesi).Alumni Jurusan Biologi, Fakultas Matematika dan IImu Pengetahuan Alam 
Universitas Sam Ratulangi Manado. Jurusan Biologi, Fakultas Matematika dan IImu Pengetahuan Alam Universitas Sam Ratulangi Manado. Jurnal Bioslogos Vol 3 No 1 Hal 26-31

Samuel, P. Wiadnya, D. Yanuwiadi, B. 2017. Species and Abundance of Sea Urchins (Diadematidae) on Different Environmental Pressure Conditions, Department of Post Graduate Program, Study Program of Environmental Resources Management and Development, Brawijaya University, Malang, Indonesia, Faculty of Fisheries and Marine Sciences, Brawijaya University, Malang, Indonesia.

Schoppe, S. 2000 A guide to common shallow water sea stars, brittle stars, sea urchins, sea cucumbers and feather stars (echinoderms) of the Philippines. Times Media Private Limited, Singapore. Hal 01-44.

Shannon, C.E. dan Weaver, W., 1949. The Mathematical Theory of Communication. Urbana: University of Illinois Press.

Zamani, N.P. 2015. Kondisi Terumbu Karang Dan Asosiasinya Dengan Bintang Laut Di Perairan Pulau Tunda, Kabupaten Seram, Provinsi Banten. Departemen IImu dan Teknologi Kelautan Fakulltas Perikanan dan IImu Kelautan, Institut Pertanian Bogor. Jurnal Teknologi Perikanan dan Kelautan Vol. 6 No. 1 